\title{
Fate of organic compounds during transformation of ferrihydrite in iron formations
}

\author{
S. Jelavić1,2*, A.C. Mitchell ${ }^{3}$, K.K. Sand ${ }^{1,2,3}$
}

Abstract

doi: 10.7185/geochemlet.2030

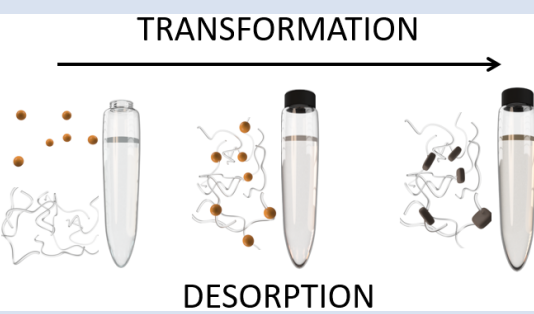

groups, and measured the amount of mineral as: formation releases glycerol highlighting that organic compounds adsorbed at precursor ferrihydrite could be desorbed during the process of IF sedimentation and diagenesis. Our results suggest that the absence of organic compounds in IF should not be used as evidence against their biogenic origin.

Received 20 March 2020 | Accepted 7 August 2020 | Published 15 September 2020

\section{Introduction}

Traditionally, iron formations (IFs) have been considered as abiotically generated chemical sediments but an increasing body of evidence suggests the active role of microbes in their precipitation (Koehler et al., 2010). The role of anoxygenic phototrophic bacteria in the formation of IFs has been the object of speculation since the work of Garrels et al. (1973). An improved understanding of microbially induced $\mathrm{Fe}$ (II) oxidation highlights that oxidising bacteria, such as Rhodobacter ferrooxidans, could likely drive the formation of IFs (Kappler et al., 2005). Further, mass balance calculations have shown that Fe(II)-oxidising phototrophic bacteria have the capacity to oxidise all Fe(II) from the Precambrian ocean, causing formation of iron (oxyhydr)oxide (FeOx) (Hegler et al., 2008). However, the low concentration of organic compounds in IFs and their diagenetic or metamorphic derivatives, challenges the hypothesis of their biogenic origin (Klein, 2005).

Extracellular polymeric substances (EPS) promote FeOx nucleation (Sand et al., 2020) where microbially formed FeOx are often found in close association with the EPS (Chan et al., 2004). When EPS is encrusted with FeOx, the polymers are shed and new EPS are formed. This prevents the encrustation of the microbe itself (Phoenix et al., 2000; Chan et al., 2004). During IF formation, FeOx-EPS composites would have settled through the water column and been deposited on the sea floor. Some of the organic compounds were degraded by diagenetic and metamorphic processes (Köhler et al., 2013; Posth et al., 2013; Halama et al., 2016). In addition, there is evidence that the depositional environment was most likely scarce in organic compounds (Dodd et al., 2019). Thus, the majority of the organic compounds was likely lost prior to deposition.

Hematite is a major component of IFs found today (Konhauser et al., 2017) but, initially, the FeOx in the FeOxpolymer complexes were most likely composed of ferrihydrite (Chan et al., 2004). The transformation to hematite would have happened in aqueous solutions both before (Sun et al., 2015) and after deposition on the seabed. Depending on the solution conditions, ferrihydrite to hematite transformation can involve intermediary phases such as lepidocrocite and goethite, e.g., through Fe(II) catalysed transformation (Hansel et al., 2003), or it can be direct (Cudennec and Lecerf, 2006). Transformation involving intermediary phases is a dissolution-precipitation process (Schwertmann and Murad, 1983) implying that the interface between ferrihydrite and organic compounds is eliminated. In this scenario, organic compounds would have been released to solution where they could have been re-adsorbed but less strongly bound to newly formed phases (Chen et al., 2015), or released in the water column and subsequently degraded by various biotic and abiotic processes (Kleber et al., 2015). The direct transformation from ferrihydrite to hematite is a solid-state transition where atoms move only locally to occupy new structural positions (Cudennec and Lecerf, 2006), without the loss of an interface with adsorbed complexes. Thus, the direct transformation of ferrihydrite to hematite is not necessarily accompanied by a removal of organic compounds. However, the Gibbs free energy of binding $\left(\Delta G_{b u}\right)$

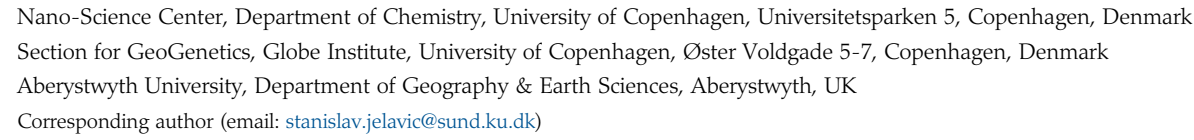


between ferrihydrite and EPS is larger than between hematite and EPS (Sand et al., 2020) implying that the polymers were more likely to desorb from hematite than from ferrihydrite. In such a case, the absence of organic compounds in IFs cannot be an argument against their biogenic origin.

To understand better the fate of adsorbed organic compounds during direct transformation from ferrihydrite to hematite, we used dynamic force spectroscopy (DFS) to measure the energy of binding between hematite and representative organic functional groups found in EPS. Subsequently we identified the functional group least likely to desorb during transformation and carried out transformation experiments where we used thermogravimetric analysis (TGA) to measure the loss of organic compounds during transformation.

\section{Materials and Methods}

DFS. We used an Asylum MFP3D atomic force microscope (AFM) and functionalised gold coated AFM tips (MSCT, Bruker) with carboxyl $\left(\mathrm{COO}^{-}\right)$, hydroxyl $(\mathrm{OH})$, and phosphate $\left(\mathrm{HPO}_{4}^{-}\right)$headgroups pointing away from the AFM probe (Fig. 1a). Tips were functionalised following the protocol described in Jelavić et al. (2017) (details in SI).

We used the $\{0001\}$ face for DFS because it is one of the most common hematite surfaces in the environment (Hartman, 1989) and because it is a predominant face on hematite produced by transformation of ferrihydrite (Cornell and Schwertmann, 2004). The specular hematite monocrystal $\{0001\}$ face was cleaned prior to analysis following the protocol described in Jelavić et al. (2017) (details in the SI). For DFS measurements, we collected $>500$ force curves per experiment. The tip approaching velocity was set to $500 \mathrm{nms}^{-1}$ and the retraction velocity varied between $10-10000 \mathrm{nms}^{-1}$. The trigger force was set to $100 \mathrm{pN}$ and dwell time to $0.5 \mathrm{~s}$. During the measurement, the head groups bound to the hematite surface (Fig. 1a) and we measured the forces applied to break the bond (i.e. the force curve, Fig. 1b). We fit the rupture forces $v$ s. the loading rate to a multibond model (Friddle et al., 2012) enabling calculation of $\Delta G_{b u}$ (Eq. S-1 to Eq. S-4). The measurements were done in $10 \mathrm{mM} \mathrm{NaCl}$ solution at $\mathrm{pH}=5.6$. We chose these conditions, rather than conditions at which the transformation experiments were conducted, to maximise the interaction forces between the tip and hematite surface (Lützenkirchen et al., 2013; Newcomb et al., 2017).

Transformation experiments. Ferrihydrite was synthesised using the method of Schwertmann and Cornell (2000). We used $0.5 \mathrm{M} \mathrm{NaCl}$ solution and $\mathrm{pH}=7$ as a proxy for Precambrian seawater. We chose glycerol $\left(\mathrm{CH}_{2} \mathrm{OH}-\mathrm{CHOH}-\mathrm{CH}_{2} \mathrm{OH}\right)$ as a model for an $\mathrm{OH}$-rich molecule. Adsorption of polymers is a complex function of degree of branching, length and hydrophobicity (van Oss, 1997). The aim here is not to account for such variations but to isolate the effect of $\Delta G_{b u}$, which is independent of those parameters, on the magnitude of desorption during transformation. Coprecipitation of ferrihydrite-polymer aggregates results in a high organic content compared to adsorbed polymers (Mikutta et al., 2014) and can cause variations in grain size and aggregation. To avoid any influence from such variations and to avoid low transformation rates related to high surface coverage, we adsorbed glycerol to ferrihydrite in this study. We mixed $15 \mathrm{mg}$ of ferrihydrite with $15 \mathrm{ml}$ of $0.5 \mathrm{M} \mathrm{NaCl}$ and added glycerol to a final concentration of $0.5 \%$ (Fig. 1c). In control samples, we omitted glycerol. Samples were shaken at $100 \mathrm{rpm}$ overnight to equilibrate. The next day, a batch of samples was rinsed with $20 \mathrm{ml}$ of rinsing stock solution $(0.5 \mathrm{M} \mathrm{NaCl}$ adjusted to $\mathrm{pH}=7$ with $1 \mathrm{M} \mathrm{NaOH}$ ) by ultra-centrifugation (equilibrated sample).
Another batch was placed in the oven heated to $90^{\circ} \mathrm{C}$. The samples from the oven were sampled at specific time steps to follow the transformation pathway using X-ray diffraction (XRD). When sampled, a batch was rinsed with $20 \mathrm{ml}$ of $0.5 \mathrm{M} \mathrm{NaCl}$ that was adjusted to $\mathrm{pH}=7$ (aged sample). All samples were freeze dried after rinsing.

$X R D$. Samples for $X R D$ were washed with ultra-deionised water (resistivity $>18.2 \mathrm{M} \Omega \mathrm{cm}$ ). A volume of $1.5 \mathrm{ml}$ of suspension was pipetted on the zero background Si holders and left to dry at room temperature. Such sample preparation results in large preferred orientation of anisotropic grains such as goethite and lepidocrocite and allows us to detect minute quantities of crystalline material in a poorly ordered matrix of ferrihydrite. We collected diffractograms in reflection mode on the Bruker D8 Advance instrument using $\mathrm{Cu} K \alpha$ radiation $(\lambda=1.5418 \AA)$ operated at $40 \mathrm{kV}$ and $40 \mathrm{~mA}$, and a LynxEye detector. Diffractograms were collected from $10-90^{\circ} 2 \theta$ with step size of $0.02^{\circ}$ and $1.7 \mathrm{~s}$ counting time per step. The sample was spun at $20 \mathrm{rpm}$. We used $0.3^{\circ}$ divergence and $3^{\circ}$ antiscatter slits, $2.5^{\circ}$ Soller slits on incident and diffracted beams and a $0.02 \mathrm{~mm}$ thick Ni-filter. The opening of detector window was $2.94^{\circ}$.

TGA. We used Netzsch TG 209 F1 Libra. Samples were heated at a rate of $10{ }^{\circ} \mathrm{C} \mathrm{min}-1$ from 30 to $1000{ }^{\circ} \mathrm{C}$ under $\mathrm{N}_{2}$ atmosphere. $\sim 15 \mathrm{mg}$ of sample were placed into the Pt crucible and the weight loss was measured as a function of temperature.

TEM. Images were taken with a Philips CM 20 TEM equipped with a thermionic $\mathrm{LaB}_{6}$ filament. We used an accelerating voltage of $200 \mathrm{kV}$. Samples were prepared by placing a droplet of sample suspension on a formvar coated TEM grid and left for 5-10 s. Subsequently, the grid was washed in ultra-deionised water and water droplets were removed with the edge of a paper towel.

\section{Results and Discussion}

Energy of binding. The force spectra (Fig. 2) show that the rupture force between hematite and the $\mathrm{OH}$ group is $\sim 6$ times higher than between $\mathrm{COO}^{-}$and $\mathrm{HPO}_{4}^{-}$groups (Fig. 2, Table S-1). Recalculated to $\Delta G_{b u}$ (Eq. S-4), that is an increase in $\sim 2 \mathrm{kT}$. These binding energies suggest that the interaction is dominated by strong Van der Waals or weak electrostatic forces (Israelachvili, 2011). Considering that the $\{0001\}$ hematite surface is completely hydroxylated in water (Trainor et al., 2004), our results follow the trend where $\mathrm{OH}-\mathrm{OH}$ bonds are twice as strong as $\mathrm{COO}^{-}-\mathrm{OH}$ bonds at circumneutral $\mathrm{pH}$ (Vezenov et al., 1997) present in Precambrian ocean. Thus, irrespective of the transformation pathway, biopolymers rich in acidic groups desorb more easily from hematite than those rich in hydroxyl groups.

Transformation pathway. To investigate the fate of a ferrihydrite-associated $\mathrm{OH}$-containing molecule during transformation to hematite, we transformed the ferrihydrite-glycerol complex, monitored the transformation pathway with XRD and determined the weight loss with TGA. The ferrihydriteglycerol complex transformed directly to hematite without any intermediate phases detectable by XRD (Fig. S-3) suggesting a solid-state transformation pathway. As a control, we transformed ferrihydrite in absence of glycerol using the same solution conditions. Even though the hematite was the first phase to occur after $17 \mathrm{hr}$, goethite started forming after $43 \mathrm{hr}$ (Fig. S-2) indicating that, in pure systems, some ferrihydrite dissolves and reprecipitates as goethite, as previously shown (Das et al., 2011).

The transformation is accompanied by glycerol release. In general, the ferrihydrite-gycerol complex lost more weight than the pure ferrihydrite (Fig. 3, Table 1). Ferrihydrite is more 
(a)
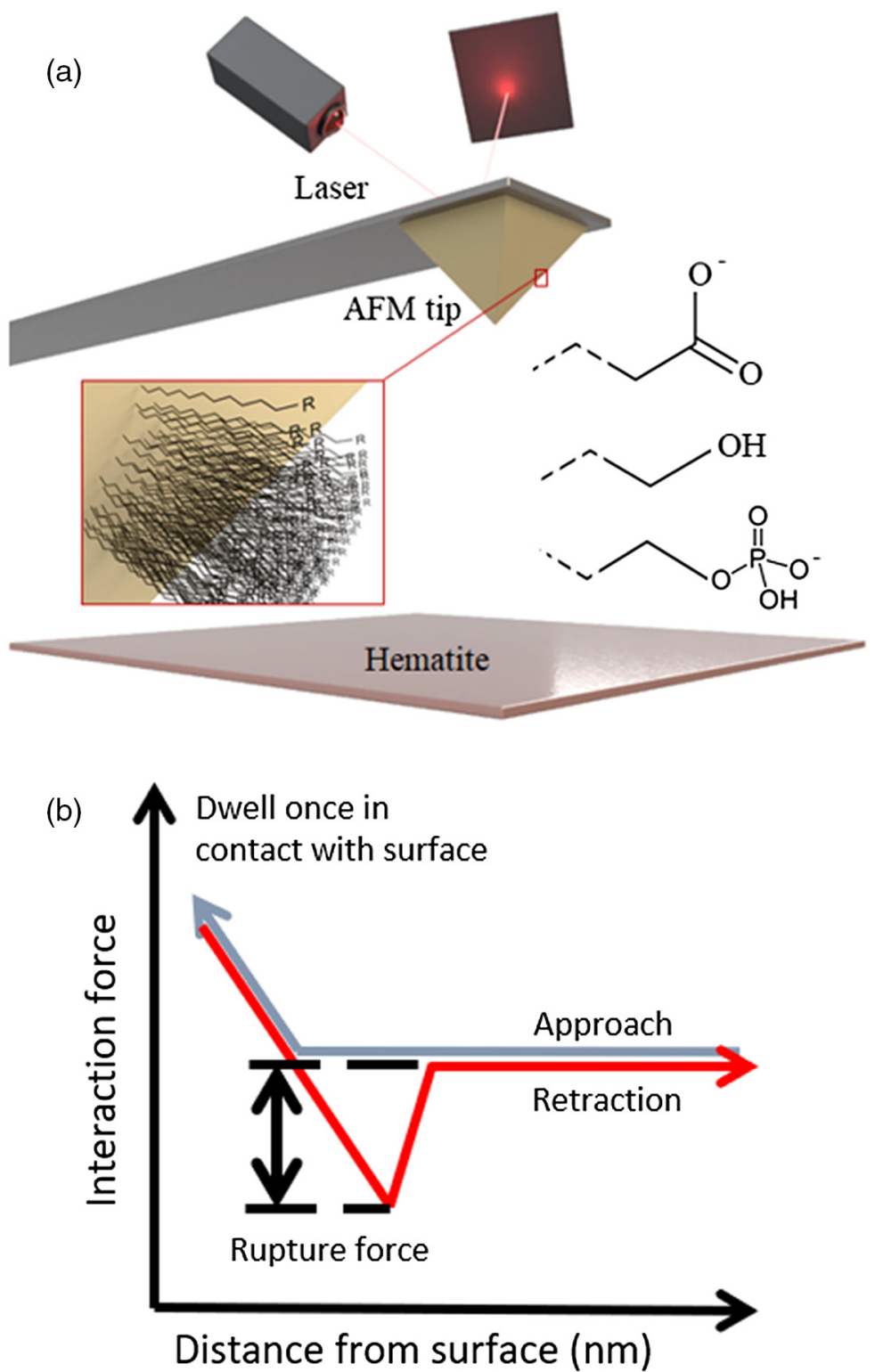

(c) Mixing (RT)

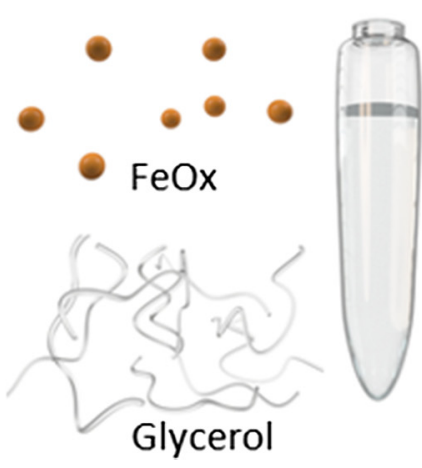

Equilibrated (RT)

"Before transformation"

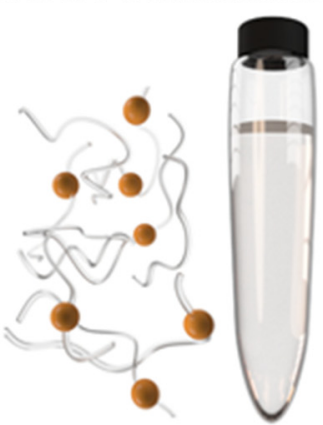

Aged at $90^{\circ} \mathrm{C}$

"After transformation"

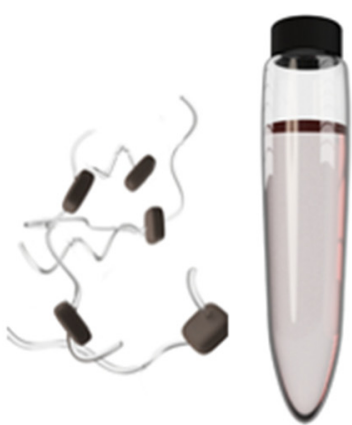

Figure 1 (a) Schematics of the DFS (Dynamic Force Spectroscopy): self assembled monolayers with carboxyl, hydroxyl and phosphate headgroups covalently bonded to AFM tip. (b) A scheme of a force curve. (c) In transformation experiments, ferrihydrite and glycerol were mixed at room temperature and left to equilibrate overnight. One sample was then taken for TGA (equilibrated sample) and the rest was placed in the oven at $90{ }^{\circ} \mathrm{C}$ until the transformation was complete (aged sample). 


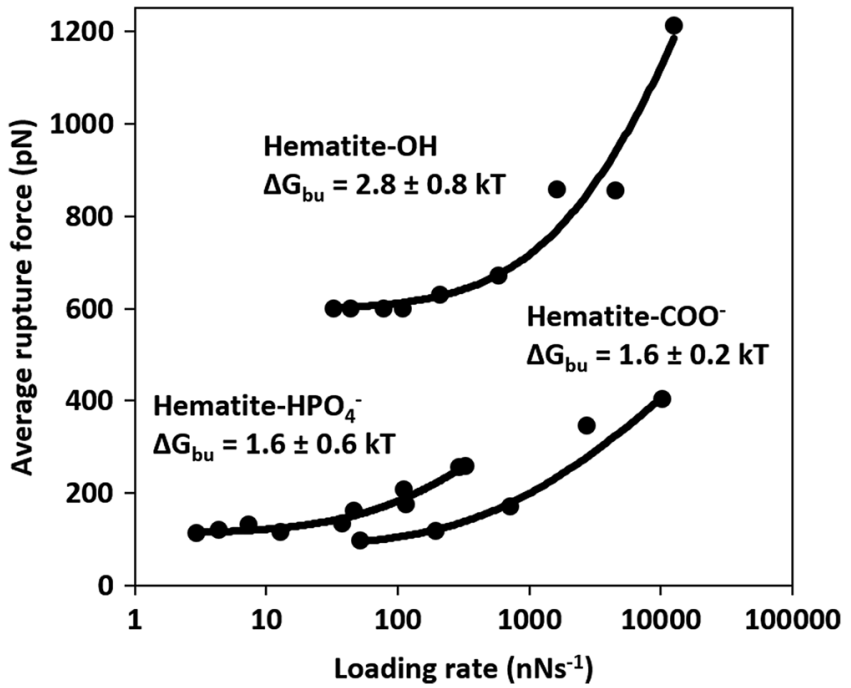

Figure 2 Multibond fit (Friddle et al., 2012) to the dynamic force spectra between hematite surface and alkyl thiol self assembled monolayers with $\mathrm{OH}, \mathrm{HPO}_{4}^{-}$and $\mathrm{COO}^{-}$head groups. The uncertainty represents the error propagated from the standard deviations of the fit. Loading rate is a nominal retraction velocity $\left(\mathrm{nms}^{-1}\right)$ multiplied with the spring constant of the cantilever $\left(\mathrm{nNnm}^{-1}\right)$.

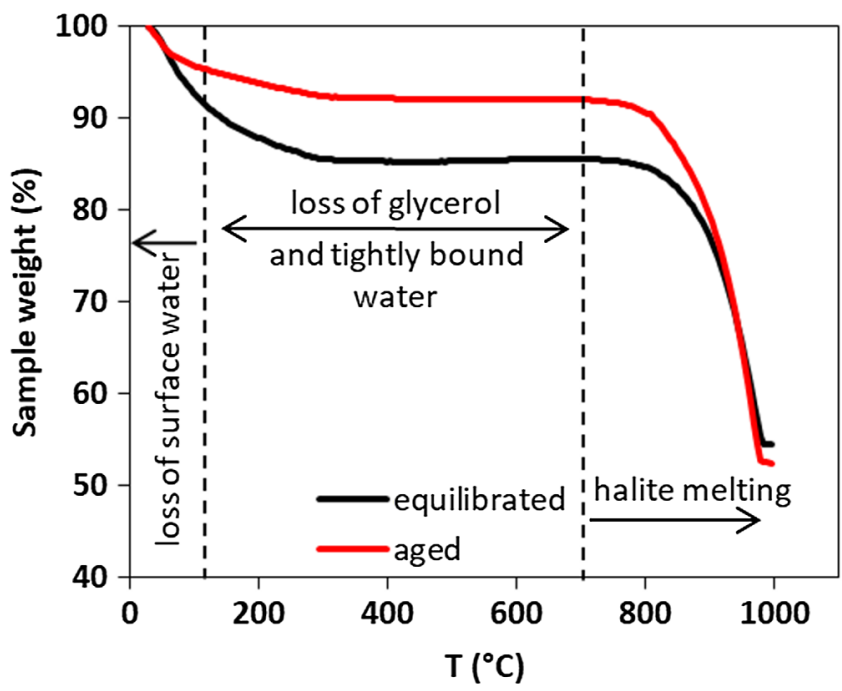

Figure 3 Comparison of thermogravimetry curves of ferrihydriteglycerol (equilibrium-black curve) and resulting hematite-glycerol (aged-red curve). The smaller mass loss in the region $125-700{ }^{\circ} \mathrm{C}$ (dashed vertical lines) for the aged sample compared to the equilibrium sample suggests bigger loss of tightly bound water and glycerol during the transformation.

Table 1 Weight loss during the TGA analysis in $<125{ }^{\circ} \mathrm{C}$ and $125-700{ }^{\circ} \mathrm{C}$ regions.

\begin{tabular}{|l|l|c|c|}
\hline \multicolumn{2}{|c|}{} & \multicolumn{2}{|c|}{$\%$ weight loss } \\
\cline { 3 - 4 } Sample & $<125{ }^{\circ} \mathrm{C}$ & $125-700{ }^{\circ} \mathrm{C}$ \\
\hline \multirow{2}{*}{ Glycerol } & equilibrated & 8.9 & 5.4 \\
& aged & 4.8 & 3.2 \\
& equilibrated & 9.8 & 4.7 \\
& aged & n.a. ${ }^{*}$ & n.a. \\
\hline
\end{tabular}

* transformation yielded both goethite and hematite making comparison impossible hydrated than hematite so the loss of loosely adsorbed water $\left(<125^{\circ} \mathrm{C}\right)$ and tightly bound water $\left(125-700{ }^{\circ} \mathrm{C}\right)$ is higher for ferrihydrite than hematite (Hiemstra and Van Riemsdijk, 2009). Comparing the weight loss of ferrihydrite-glycerol (5.4\%; Table 1) to pure ferrihydrite $(4.7 \%)$ in the $125-700{ }^{\circ} \mathrm{C}$ range, shows that the tightly bound water accounts only for $87 \%$ of the weight loss in this region, indicating that the remaining $13 \%$ is the loss of glycerol and associated interfacial water. This implies that hematite produced by aging ferrihydrite-glycerol contains less glycerol than the original ferrihydrite-glycerol (equilibrated), and that glycerol is released during transformation. Considering that the initial amount of adsorbed glycerol is $\sim 5 \mathrm{mg} / \mathrm{g}$ of ferrihydrite (Fig. S-1), TGA indicates that all glycerol has been desorbed during the transformation

The reason for the loss of the glycerol during transformation can also be the smaller specific surface area (SSA) of the produced hematite (Fig. S-4) and not only the lower affinity for glycerol compared to ferrihydrite. From TEM images, we estimated the SSA of ferrihydrite to be $374-790 \mathrm{~m}^{2} \mathrm{~g}^{-1}$ and of hematite to be $10-46 \mathrm{~m}^{2} \mathrm{~g}^{-1}$. Thus, the decrease in the SSA because of grain coarsening during transformation is between 9-70 times which alone might explain the decrease in glycerol content. However, the loss must be amplified by the lower $\Delta G_{b u}$ for hematite- $\mathrm{OH}$ than for ferrihydrite- $\mathrm{OH}$ system. In addition, our thermodynamic results suggest that the loss of organic compounds would have happened because of decreased $\Delta G_{b u}$ even if the subsequent grain coarsening does not occur, e.g., in case of hematite growth inhibition caused by organic compounds. However, both scenarios are likely to have contributed to the loss of organic compounds during the formation of IFs.

We have demonstrated that glycerol, a molecule with a high $\Delta G_{b u}$ to hematite, desorbs during the transformation of ferrihydrite to hematite. We propose that a significant mass of organic compounds from FeOx-EPS composites is desorbed early in the process of FeOx sedimentation because of the transformation from ferrihydrite to hematite. This loss of organic compounds is probably further enhanced by the grain coarsening of hematite during diagenetic and metamorphic processes and concomitant reactions in the microenvironment that result in secondary mineralisation, e.g., Posth et al. (2013). Our experiments were designed to determine the loss of strongly bound molecules from FeOx during the direct transformation, which is least likely to result in desorption of adsorbed organic compounds. The less strongly bound organic compounds or organic compounds adsorbed to ferrihydrite that transformed via dissolution-precipitation pathway would likely have desorbed in higher proportion than that we report here. Thus, our results highlight that the absence of organic compounds in IF should not be used as evidence against their biogenic origin.

\section{Acknowledgements}

We thank Heloisa N. Bordallo for access to TGA instrument (Carlsbergfondets, grant no. 2013_01_0589). KKS and ACM are grateful for funding from the European Union's Horizon 2020 Research and Innovation Programme under Marie Skłodowska-Curie Grant Agreement No 663830 and the Welsh Government and Higher Education Funding Council for Wales through the Sêr Cymru National Research Network for Low Carbon, Energy and Environment. KKS is grateful for funding from the Danish Council for Independent Research Sapere Aude Programs (0602-02654B).

Editor: Karim Benzerara 


\section{Additional Information}

Supplementary Information accompanies this letter at http:// www.geochemicalperspectivesletters.org/article2030.

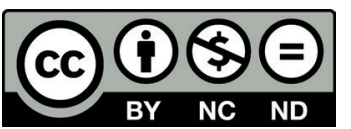

(C) 2020 The Authors. This work is distributed under the Creative Commons Attribution NonCommercial No-Derivatives 4.0 License, which permits unrestricted distribution provided the original author and source are credited. The material may not be adapted (remixed, transformed or built upon) or used for commercial purposes without written permission from the author. Additional information is available at http://www. geochemicalperspectivesletters.org/copyright-and-permissions.

Cite this letter as: Jelavić, S., Mitchell, A.C., Sand, K.K. (2020) Fate of organic compounds during transformation of ferrihydrite in iron formations. Geochem. Persp. Let. 15, 25-29.

\section{References}

Chan, C.S., Stasio, G.D., Welch, S.A., Girasole, M., Frazer, B.H., Nesterova, M.V. FAKRA, S., BANFIELD, J.F. (2004) Microbial Polysaccharides Template Assembly of Nanocrystal Fibers. Science 303, 1656-1658.

Chen, C., KuKKadapu, R., Sparks, D.L. (2015) Influence of Coprecipitated Organic Matter on $\mathrm{Fe}^{2+}{ }_{(\mathrm{aq})}$-Catalyzed Transformation of Ferrihydrite: Implications for Carbon Dynamics. Environmental Science \& Technology 49, 10927-10936.

CoRnell, R.M., Schwertmann, U. (2004) Crystal Morphology and Size. In: The Iron Oxides. Wiley-VCH Verlag Gmbh \& Co., Weinheim, 59-94.

CudenneC, Y., LeCERF, A. (2006) The transformation of ferrihydrite into goethite or hematite, revisited. Journal of Solid State Chemistry 179, 716-722.

Das, S., Hendry, M.J., Essilfie-Dughan, J. (2011) Transformation of Two-Line Ferrihydrite to Goethite and Hematite as a Function of $\mathrm{pH}$ and Temperature. Environmental Science \& Technology 45, 268-275.

Dodd, M.S., Papineau, D., Piraino, F., Wan, Y., Karhu, J.A. (2019) Minimal biomass deposition in banded iron formations inferred from organic matter and clay relationships. Nature Communications 10, 1-13.

FRIDdLE, R.W., NoY, A., YoReO, J.J.D. (2012) Interpreting the widespread nonlinear force spectra of intermolecular bonds. Proceedings of the National Academy of Sciences 109, 13573-13578.

Garrels, R.M., Perry, E.A., MackenZie, F.T. (1973) Genesis of Precambrian IronFormations and the Development of Atmospheric Oxygen. Economic Geology 68, 1173-1179.

Halama, M., Swanner, E.D., Konhauser, K.O., Kappler, A. (2016) Evaluation of siderite and magnetite formation in BIFs by pressure-temperature experiments of Fe(III) minerals and microbial biomass. Earth and Planetary Science Letters 450, 243-253.

Hansel, C.M., Benner, S.G., Neiss, J., Dohnalkova, A., KukKadapu, R.K., Fendorf, S. (2003) Secondary mineralization pathways induced by dissimilatory iron reduction of ferrihydrite under advective flow. Geochimica et Cosmochimica Acta 67, 2977-2992.

Hartman, P. (1989) The effect of surface relaxation on crystal habit: Cases of corundum $\left(\alpha-\mathrm{Al}_{2} \mathrm{O}_{3}\right)$ and Hematite $\left(\alpha-\mathrm{Fe}_{2} \mathrm{O}_{3}\right)$. Journal of Crystal Growth $96,667-672$.

Hegler, F., Posth, N.R., Jiang, J., Kappler, A. (2008) Physiology of phototrophic iron(II)-oxidizing bacteria: implications for modern and ancient environments. FEMS Microbiology Ecology 66, 250-260.

HIEMSTRA, T., VAN RIEMSDIJK, W.H. (2009) A surface structural model for ferrihydrite I: Sites related to primary charge, molar mass, and mass density. Geochimica et Cosmochimica Acta 73, 4423-4436.

IsraelachVili, J.N. (2011) Intermolecular and Surface Forces. Third edition, Elsevier, Burlington.

Jelavić, S., Tobler, D.J., Hassenkam, T., Yoreo, J.J.D., Stipp, S.L.S., Sand, K.K. (2017) Prebiotic RNA polymerisation: energetics of nucleotide adsorption and polymerisation on clay mineral surfaces. Chemical Communications 53, 12700-12703.

Kappler, A., Pasquero, C., Konhauser, K.O., Newman, D.K. (2005) Deposition of banded iron formations by anoxygenic phototrophic Fe(II)-oxidizing bacteria. Geology 33, 865-868.

Kleber, M., Eusterhues, K., Keiluweit, M., Mikutta, C., Mikutta, R., Nico, P.S. (2015) Chapter One - Mineral-Organic Associations: Formation, Properties, and
Relevance in Soil Environments. In: Sparks, D.L. (Ed.) Advances in Agronomy. Academic Press, Cambridge, 1-140.

KLEIN, C. (2005) Some Precambrian banded iron-formations (BIFs) from around the world: Their age, geologic setting, mineralogy, metamorphism, geochemistry, and origins. American Mineralogist 90, 1473-1499.

Koehler, I., Konhauser, K., Kappler, A. (2010) Role of Microorganisms in Banded Iron Formations. In: BARTON, L.L., MANDL, M., LoY, A (Eds.) Geomicrobiology: Molecular and Environmental Perspective. Springer Netherlands, Dordrecht, 309-324.

Köhler, I., Konhauser, K.O., Papineau, D., BekKer, A., Kappler, A. (2013) Biological carbon precursor to diagenetic siderite with spherical structures in iron formations. Nature Communications 4, 1-7.

Konhauser, K.O., Planavsky, N.J., Hardisty, D.S., Robbins, L.J., Warchola, T.J. Haugaard, R., Lalonde, S.V., Partin, C.A., Oonk, P.B.H., Tsikos, H., Lyons, T.W., BeKKer, A., Johnson, C.M. (2017) Iron formations: A global record of Neoarchaean to Palaeoproterozoic environmental history. Earth-Science Reviews 172, 140-177.

LÜtZenkirchen, J., Preočanin, T., Stipić, F., Heberling, F., Rosendvist, J., Kallay, N. (2013) Surface potential at the hematite (001) crystal plane in aqueous environments and the effects of prolonged aging in water. Geochimica et Cosmochimica Acta 120, 479-486.

Mikutta, R., Lorenz, D., Guggenberger, G., Haumaier, L., Freund, A. (2014) Properties and reactivity of Fe-organic matter associations formed by coprecipitation versus adsorption: Clues from arsenate batch adsorption. Geochimica et Cosmochimica Acta 144, 258-276.

Newcomb, C.J., QAfoku, N.P., Grate, J.W., Bailey, V.L., Yoreo, J.J.D. (2017) Developing a molecular picture of soil organic matter-mineral interactions by quantifying organo-mineral binding. Nature Communications 8, 396.

Phoenix, V.R., Adams, D.G., Konhauser, K.O. (2000) Cyanobacterial viability during hydrothermal biomineralisation. Chemical Geology 169, 329-338.

Posth, N.R., KöHler, I., Swanner, E.D., Schröder, C., Wellmann, E., Binder, B. Konhauser, K.O., Neumann, U., Berthold, C. NowaK, M., Kappler, A. (2013) Simulating Precambrian banded iron formation diagenesis. Chemical Geology, Special Issue dedicated to H.D. Holland: Evolution of the atmosphere and ocean through time 362, 66-73.

Sand, K.K., Jelavić, S., Dobberschütz, S., Ashby, P.D., Marshall, M.J., Dideriksen, K., Stipp, S.L.S., Kerisit, S.N., Friddle, R.W., DeYoreo, J.J. (2020) Mechanistic insight into biopolymer induced iron oxide mineralization through quantification of molecular bonding. Nanoscale Advances 2, 3323-3333.

Schwertmann, U., Cornell, R.M. (2000) Ferrihydrite. In: Iron Oxides in the Laboratory. John Wiley \& Sons, Ltd, Weinheim, 103-112.

Schwertmann, U., Murad, E. (1983) Effect of pH on the Formation of Goethite and Hematite from Ferrihydrite. Clays and Clay Minerals 31, 277-284.

Sun, S. Konhauser, K.O., Kappler, A., Li, Y.-L. (2015) Primary hematite in Neoarchean to Paleoproterozoic oceans. GSA Bulletin 127, 850-861.

Trainor, T.P., ChaKa, A.M., Eng, P.J., Newville, M., Waychunas, G.A., CAtalano, J.G., BRown, G.E. (2004) Structure and reactivity of the hydrated hematite (0001) surface. Surface Science 573, 204-224.

van Oss, C.J. (1997) Hydrophobicity and hydrophilicity of biosurfaces. Current Opinion in Colloid \& Interface Science 2, 503-512.

Vezenov, D.V., Noy, A., Rozsnyai, L.F., Lieber, C.M. (1997) Force Titrations and Ionization State Sensitive Imaging of Functional Groups in Aqueous Solutions by Chemical Force Microscopy. Journal of the American Chemical Society 119, 2006-2015 